Developments in Plant Breeding For Improved Nutritional Quality of Soya Beans I. Protein and Amino Acid Content

E J Clarke and J. Wiseman*

School of Biological Sciences, University of Nottingham, Sutton Bonington Campus, Loughborough, Leics. LE12 5RD, UK

* Corresponding author.

Tel.:(0115) 9516054

Fax.:(0115) 9516060;

E-mail: julian.wiseman@nottingham.ac.uk

Short title: Improving protein content and quality of soya beans

(Journal of Agricultural Science $1^{\text {st }}$ June 1999) 
Soya beans, like other legumes, contain low concentrations of the nutritionally essential sulphur amino acid, methionine. Cysteine, although not an essential amino acid because it can be synthesized from methionine, also influences the nutritional quality of soya bean products when it is only present in low levels. A low cysteine content will also aggravate a methionine deficiency.

Soya bean lines deficient in 7S protein subunits have been identified. The 7S proteins contain substantially less methionine and cysteine than the 11S proteins. With the myriad of genetic null alleles for these subunits it may be possible to tailor the $7 S / 11 S$ storage protein ratio and their total composition in seeds to include only those subunits with the richest sulphur amino acid composition.

Cotyledon feeding experiments, using isolated soya bean cotyledons, demonstrated that addition of methionine to the culture media caused increased synthesis of both proteins and free amino acids but the mechanism by which this takes place is not clear.

Biotechnological approaches to improve nutritional value of soya beans include elevated expression of genes that originate from other species which encode high-sulphur proteins. High level expression of a $2 \mathrm{~S}$ Brazil nut albumin gene in soya bean resulted raised methionine concentration although the Brazil nut gene is highly antigenic and therefore will not be useful in production agriculture.

Modification of glycinin to increase sulphur amino acid content is possible, and these gene products are capable of normal assembly into trimers in vitro although are rapidly degraded in vivo by the asparaginyl endopeptidase responsible for post-translational modification of proglycinin.

Solutions to the methionine deficiency may be anticipated from a combination of approaches followed in laboratories worldwide. Many of these approaches are not without difficulty but, despite this, the likelihood is that soya beans with improved nutritional quality (which may not be confined to sulphur-containing amino acids as other nutritionally essential amino acids are also valuable) will be available in the near future. It will be essential to confirm that the increased total methionine (or other amino acid) is digestible to the animal to at least the same degree as conventional cultivars. 
Although soya beans are perhaps the most important legume crop worldwide, there are still problems relating to its nutritional value including deficiency of sulphur-containing and other amino acids. Enhanced nutritional quality of soya beans, achieved through increasing the concentration of nutritionally essential amino acids, improves their nutritional value and would further enhance its role as a key raw material for inclusion into diets for non-ruminants.

Although economic analyses are transient, linear programming optimization routines (University of Nottingham, unpublished data) employed in diet formulation indicate that the commercial value of a $10 \%$ improvement in concentration of lysine, methionine and threonine is associated with an increase in the value of the crop of $£ 3.4$ - $£ 7.1, £ 2.0$ and $£ 4.4$ / $\mathrm{T}$ respectively. Although value in this context is influenced by the precise circumstances under which the routines are run (for example relative price of other raw materials and nutrient content of diets), the data nevertheless indicate that it is not just an increase in methionine which would be beneficial and that a general elevation in protein content would also be useful.

There has been a considerable research effort directed towards the improvement in the quality of soya beans and this review will cover the potential for improving protein quality. Alterations of seed storage protein ratios offer the possibility of increasing amino acid content, particularly methionine, and high protein cultivars are also now being developed.

\section{PROTEIN QUALITY}

The soya bean belongs to the family Leguminosae, subfamily Papilionoideae, and the genus Glycine L. The cultivated form, Glycine max L. Merrill, grows annually. Its plant is bushy with height ranging from 0.75 to $1.25 \mathrm{~m}$, branching sparsely or densely, depending on cultivars and growing conditions. Most mature seeds consist of three basic parts: the seed coat, the embryo and one or more storage structures. However, the soya bean seed, as in most leguminous plants, is essentially devoid of endosperm and consists of a seed coat and a large, well-developed embryo. The embryo contains two cotyledons which function as food reserves. During seed maturation the cells of the cotyledons are filled with starch grains (about 5Фm in 
diameter), lipid bodies, and protein bodies. The starch grains are converted to other components during the last few days of maturation, so very little starch (less than $10 \mathrm{mg} / \mathrm{g}$ ) is found in mature soya bean seeds. The proximate composition of the different structural parts of soya beans varies (e.g. Wolf \& Cowan 1975), for example the hull contains the greatest concentration of non-starch polysaccharides (NSP but have the lowest content of protein and lipid.

Based on biological function in plants, seed proteins are of two types: metabolic and storage. Metabolic proteins include enzymatic and structural proteins and are involved in normal cellular activities, including synthesis of storage proteins which, together with oil reserves, occurs during seed development. Following seed germination, they provide a source of nitrogen and carbon skeletons for the developing seedling. The majority of soya bean protein is storage protein.

Legume seed proteins are divided into albumins and globulins, a distinction which is based on solubility patterns. Albumins are soluble in water, whereas an early detailed study of soya bean globulins carried out by Osborne \& Campbell (1898) demonstrated that a substantial proportion of the seed protein of legumes could be extracted by dilute saline solutions which were referred to as globulins in accordance with the empirical nomenclature devised by Osborne (1924). Under this classification, most protein in soya bean protein is globulin. Two types of globulin were found in soya bean and these were named glycinin and conglycinin.

\section{Soya bean globulins}

The invention of the ultracentrifuge and subsequent studies by Danielsson (1949) led to the demonstration that glycinin and conglycinin had sedimentation coefficients of about $11 \mathrm{~S}$ and $7 \mathrm{~S}$, respectively. Ensuing reports, from researchers in both Japan and the United States, established that glycinin and conglycinin were multi-subunit proteins and account for approximately 0.7 of total protein in a typical soya bean seed (Hill \& Breidenbach 1974; Meinke et al. 1981).

\section{$\exists$-Conglycinin (7S fraction)}
In the literature, reference is made to $\forall-, \exists$ - and $\vartheta$-conglycinin. These terms were 
used originally by Catsimpoolas \& Ekenstam (1969) to refer to three immunologically distinct fractions separated from a crude conglycinin preparation. However, a subsequent report by Catsimpoolas (1969) showed that $\forall$-conglycinin contains enzymatic activities characteristic of $2 S$ fractions. $\exists$ - and $\vartheta$-conglycinins contain no enzymatic activities and are differentiated from one another on the basis of their capacity to undergo reversible polymerization at neutral $\mathrm{pH}$ in response to lowering ionic strength from 0.5 to 0.1 (Catsimpoolas 1969); $\exists$-conglycinin exhibits a sedimentation coefficient of about 7S at high ionic strengths and one of 9-10S at the lower ion concentration, whereas $\vartheta$-conglycinin fails to undergo this change. In addition, based on the method of fractional isoelectric precipitation, Thanh \& Shibasaki (1976a) reported that the former was precipitated at pH 4.8 whereas the latter remained soluble. Because of its highest proportion in the $7 \mathrm{~S}$ fraction, $\exists$-conglycinin has been studied extensively (See Table1).

(Table 1 about here)

It is now generally agreed that $\exists$-conglycinin is a trimer with a molecular weight of about $180 \mathrm{kDa}$. It has three prevalent types of subunits, designated as $\forall^{\prime}$, $\forall$ and $\exists$. The individual subunits can be resolved from one another by ion exchange chromatography after denaturation of the native complex with urea (Thanh \& Shibasaki 1976a) or by sodium dodecyl sulphate (SDS) polyacrylamide gel electrophoresis (PAGE). Based on the electrophoretic mobility of the second method, the molecular weight of the $\forall^{\prime}, \forall$ and $\exists$ subunits were estimated at 57,57 , and 42 kDa, respectively (Thanh \& Shibasaki 1976b).

Another subunit, named $\exists^{\prime}$, is present only in some soya bean varieties (Coates et al. 1985; Morita et al. 1996). The primary structure of the $\exists^{\prime}$ subunit is still unknown, but the data suggested that this subunit is rich in sulphur-containing amino acids (Coates et al. 1985). All three subunits are rich in aspartate, glutamate, leucine and arginine. The two subunits $\forall^{\prime}, \forall$ are very similar in amino acid composition. Both are devoid of cysteine and have low levels of methionine. In contrast, the $\exists$ subunit contains no methionine (Nielson 1985). All of the $\exists$-conglycinin subunits are glycoproteins and contain $40-50 \mathrm{~g}$ carbohydrate per $\mathrm{kg}$. Thus the $7 \mathrm{~S}$ globulin is considered to be glycosylated (Pernollet and Mosse 1983). 
$\exists$-conglycinin is heterogeneous with regard to subunit composition. Among the ten theoretically possible multiple forms, six $\left(B_{1}\right.$ to $\left.B_{6}\right)$ have been demonstrated to occur (Thanh \& Shibasaki 1976b). The subunit compositions of the six components are as follows: $B_{1}$ is composed of $1 \forall^{\prime}$ and $2 \exists$; $B_{2}$ is composed of $1 \forall$ and $2 \exists ; B_{3}$ is composed of $1 \forall, 1 \forall^{\prime}$ and $1 \exists ; B_{4}$ is composed of $2 \forall$ and $1 \exists$; $B_{5}$ is composed of $2 \forall$ and $1 \forall^{\prime}$ and $B_{6}$ is composed of $3 \forall$. Furthermore, $\exists$-conglycinin undergoes a complicated association-dissociation phenomenon in response to changes in ionic strength and $\mathrm{pH}$. The phenomenon was initially reported by Naismith (1955) and then confirmed by many other workers. According to Thanh \& Shibasaki (1979), the six forms of trimers are able to dimerise reversibly at low ionic strength or in the $\mathrm{pH}$ region of 4.8-11.0. The resulting $9 \mathrm{~S}$ form is a super dimer of two trimers facing each other and becomes a hexamer. At extreme $\mathrm{pH}, 2.0$ or 12.0, dissociation into subunits $\left(\forall^{\prime}, \forall\right.$ and $\exists$ ) are also reversible so that six molecular species $B_{1}$ to $B_{6}$ can be reconstituted by mixing the three subunits in urea solution and subsequently dialyzing against a phosphate buffer. Subsequent studies by other workers led to the identification of the $B_{0}$ form of $\exists$-conglycinin. It contains three subunits (Sykes \& Gayler 1981, Yamauchi et al. 1981).

Most recently, Morita et al. (1996) succeeded in isolation and purification of four major molecular components of $\exists$-conglycinin, $3 \forall, 2 \forall 1 \exists, 1 \forall 2 \exists$ and $3 \exists$, from seeds of an $\forall^{\prime}$ subunit-deficient strain. By using such cultivars with a simple subunit composition and chromatography at intermediate ionic strengths over a period sufficient to reach an effective dissociation equilibrium between the monomer and dimer, they also succeeded in crystallization of single $\exists$-conglycinin components. Consequently they were able to compare $3 \forall$ and $3 \exists$ components regarding their secondary structure and found that the $3 \forall$ component showed a higher $\forall$-helix content than $3 \exists$. Moreover, they also found two novel components from the same seeds: $2 \exists 1 \exists$ ' and $2 \exists 1$ des (V1R126) $\forall$. The former contained a subunit $\exists^{\prime}$, pointed out by Coates et al. (1985), and the latter contained a sub-component which could be derived artificially from limited hydrolysis of the $\forall$-subunit by a novel serine protease found previously in some soya bean strains (Morita et al. 1994). The proteolysis may occur in the course of extraction and purification.

Glycinin (11S fraction). 
Glycinin is the purified form of the $11 \mathrm{~S}$ globulin. It is the largest single fraction of the total seed protein (250-350 $/ \mathrm{kg}$ protein) and accounts for over 0.4 of the total seed globulin (Murphy \& Resurreccion 1984). In contrast to $\exists$-conglycinin, only a small portion of glycinin is glycosylated (Lei \& Reeck 1987).

The currently accepted model of glycinin is a hexamer with molecular weight of around $360 \mathrm{kDa}$. Its monomeric subunits have a generalized structure A-S S-B, where A represents an acidic polypeptide of $34-44 \mathrm{kDa}$; $B$ is a basic polypeptide of around 20kDa; and S-S is a single disulphide bond that links the two polypeptides. The subunits and polypeptides can be disassembled by use of urea plus a disulphide reductant such as $\exists$-mercaptoethanol. The reduced and denatured acidic polypeptide components can be resolved by chromatography with DEAE-sephadex, whereas the basic components can be separated by chromatography with CM-Sephadex (Moreira et al. 1979). Some of the peptide units of $\exists$-conglycinin, together with other seed proteins or subunits can also be separated by SDS-PAGE.

Five major subunits have been characterized, namely $A_{1 a} B_{2}, A_{1 b} B_{1 b}, A_{2} B_{1 a}, A_{3} B_{4}$ and $A_{4} A_{5} B_{3}$ (Staswick et al. 1981). Based on physical properties, these subunits can be separated into two distinct groups. Group I includes the first three subunits whilst group II includes the two remaining subunits. The group I subunits have more uniform apparent MW and contain more methionine than members of group II (see Table 2). The last feature is important for breeders to increase the methionine content in seeds.

(Table 2 about here)

Among the five major subunits, the $G 5$ subunit $\left(A_{4} A_{5} B_{3}\right)$ is an exception from the general structure. Its acidic component consists of two polypeptides, $A_{5} A_{6}$, and contains a proteolytic cleavage site approximately 100 amino acids from the amino terminal of the precursor polypeptide. Consequently the $\mathrm{A}_{4}$-component separates from the disulphide linked $A_{5} A_{6}$ component upon denaturation.

There is a genetic polymorphism of the $11 \mathrm{~S}$ globulin in soya beans. The $11 \mathrm{~S}$ globulin of standard varieties can be classified into two types, $A_{5}$ - and $A_{4}$ - types (Kitamura et al. 1980), depending on the presence or absence of the $A_{4} A_{5}$ acidic 
polypeptide component and its paired basic polypeptide. The absence of the subunit is controlled by a single recessive allele (Harada et al. 1983). Almost all the USA varieties examined to date contain all five $11 \mathrm{~S}$ subunits whilst around 0.2 of Japanese varieties lacked the $A_{4} A_{5} B_{3}$ subunit (Kitamura 1995).

Differences between glycinin and $\exists$-conglycinin globulins.

Due to differences in composition and structure, glycinin and $\exists$-conglycinin exhibit differences in both nutritional quality and functional properties. In general, the 11S globulin (glycinin) contains 3-4 time more methionine per unit protein than 7S globulin ( $\exists$-conglycinin) (Kitamura 1995). As soya bean protein is deficient in sulphur amino acids, glycinin protein is more valuable from a nutritional perspective.

Variation in total seed protein composition.

A typical soya bean contains approximately $120 \mathrm{~g}$ non-structural carbohydrate/kg, $200 \mathrm{~g} \mathrm{oil} / \mathrm{kg}$ and $400 \mathrm{~g}$ protein/ $\mathrm{kg}$ but both genetic and environmental factors strongly influence seed composition. Soya bean varieties grown commercially in the United States typically contain 360-390g protein/ $\mathrm{kg}$, although there are accessions in the US soya bean collection that approach $500 \mathrm{~g}$ protein/kg (Juvik et al. 1989a; b). The latter generally have unacceptably low yields and are not suited for production agriculture. Because seeds with high protein content are commercially important, attempts have been made to develop high protein soya bean lines. Provar (Probst et al. 1971) and Protana, (Weber \& Fehr 1970) are examples of two early varieties selected for high protein content. The varieties were not readily accepted by farmers because of the decreased yield compared to other readily available varieties. In general, protein content is inversely related to yield (Brim \& Burton 1979). Negative correlations are also often observed between soya bean oil or carbohydrate and protein content (Serretti et al. 1994)

Backcrossing, a plant breeding approach used to introgress simply inherited traits into a designated parent, has been used with limited success to improve the protein concentration of seeds (Hartwig \& Hinson 1972; Wehrman et al. 1987). A recent example of this approach is reported by Wilcox and Cavins (1995). The high 
protein trait originated from Pando (498g protein $/ \mathrm{kg}$ ), the unadapted donor parent. Cutler 71 , the adapted parent with $408 \mathrm{~g}$ protein $/ \mathrm{kg}$, was the other parent. After several backcross generations, multiple lines were identified that contained greater than $470 \mathrm{~g}$ protein $/ \mathrm{kg}$ and had yields similar to Cutler 71 . One line from a backcross-3 population was identified that contained $472 \mathrm{~g}$ protein $/ \mathrm{kg}$ and produced a greater yield than the adapted parent. Thus, while often not of value, it is possible to transfer a high protein content trait even in the face of a strong negative correlation between protein content and yield. A better understanding of the physiological and molecular events responsible for the inter-relationships between oil, protein and yield should enhance the ability of plant breeders to develop high protein soya bean varieties.

A recent breakthrough has demonstrated that the apparent negative correlation between protein, oil and yield can be overcome. Development of the cultivar Prolina has provided a more promising avenue towards improving soyabean protein quality. Achieving higher protein concentration in this variety also affected subtle changes in $11 S$ and $7 S$ composition that resulted in enhanced functional properties. Given that $11 \mathrm{~S}$ protein are enriched in sulphur-containing amino acids compared to $7 \mathrm{~S}$ proteins, the association of a higher $11 \mathrm{~S} / 7 \mathrm{~S}$ ratio with expression of the high-protein trait in Prolina provided opportunity to test the hypothesis that genetic manipultion of storage protein composition may affect nutritional quality. Work by Kwanyuen et al. (1998) showed that when expressed as a function of total mass per tonne meal, pure 11S protein from Prolina contained approximately $9.0 \mathrm{~kg}$ more methionine, cysteine and lysine than pure 11S protein from cultivar Dare, a 1.6-fold increase. Thus, improved nutritional quality may be achieved in soyabean meal by a combination of elevated $11 \mathrm{~S} / 7 \mathrm{~S}$ ratio plus increased total protein content. In Prolina, the overall gain in essential amino acid content may be enough to obviate need for nutritional supplements in feedstocks.

Although seed composition is controlled genetically, environmental factors have a strong modulating effect on seed content. For example, the number of pods per plant can be increased $30-40 \%$ by increasing light intensity by $60 \%$ during late flowering and early pod development. (Schou et al. 1978) (see Table 3). Although the total seed weight per plant is increased, the increased number of pods per node is accompanied by a decrease in seed size and a lower rate of seed fill. The increased seed weight is not the result of a light-induced increase in the production of photosynthate in leaves (Streeter \& Jeffer 1979). Instead, the substrates for 
synthesis of storage compounds are withdrawn from the nearest source (i.e. pods, stems and petioles). Compositional changes also occur when environmental conditions result in either an extension or premature termination of seed fill compared to the interval that is normal for a given soya bean genotype. The result of the extended seed development is a larger seed with increased protein and decreased oil and carbohydrate content. The opposite trends occur when environmental conditions, such as drought, hasten seed maturation (Sato \& Ikeda 1979). The physiological and biochemical events responsible for these changes are not known, although the availability of genetic probes for specific seed proteins makes exploration of these phenomena increasingly possible.

(Table 3 about here)

Whereas the preponderance of seed proteins in soya bean is either glycinin or $\exists$-conglycinin, genetic background controls the contribution of these two proteins to total protein. In addition to glycinin and $\exists$-conglycinin, certain other proteins such as the Bowman-Birk and Kunitz trypsin inhibitors, lectin, lipoxygenase and urease can each account for $20-50 \mathrm{~g} / \mathrm{kg}$ of the total seed in some soya bean cultivars. Medeiros (1982) used an immunological approach to quantify the proportion of total seed protein contributed by glycinin and $\exists$-conglycinin in 32 lines derived from a high protein breeding population. The glycinin plus $\exists$-conglycinin contents among these cultivars ranged from $377 \mathrm{~g} / \mathrm{kg}$ and $882 \mathrm{~g} / \mathrm{kg}$ of the total seed protein content with a mean of $630 \mathrm{~g} / \mathrm{kg}$. The mean total protein content of the seeds in the test was $453 \mathrm{~g} / \mathrm{kg}$, but no statistically significant relationship between total protein and the relative amount of glycinin or $\exists$-conglycinin was reported. The ratio of glycinin/ $\exists$-conglycinin ranged from 1.04 to 2.91 , with a mean of 1.63 . Even more extreme ratios of glycinin/ $\exists$-conglycinin were described by Ogawa et al. (1989), who also used an immunological response to quantify the amounts of seed storage proteins. Soya beans were described which contained abnormally low amounts of $\exists$-conglycinin, and whose seed protein had ratios of glycinin to $\exists$-conglycinin as high as 6.03 (Kitamura 1993). Because a strong negative statistical correlation existed between glycinin and $\exists$-conglycinin content in the lines, Ogawa et al. (1989) suggested that the $11 \mathrm{~S}$ globulins might be overproduced to compensate for the 
reduction in amount of the $7 \mathrm{~S}$ globulins. Thus, reports in the literature indicate that there is considerable genetic variation in the amounts of glycinin and $\exists$-conglycinin present in soya beans. Such variation may be useful in these traits can be controlled in a predictable manner.

High protein soya beans.

Currently there is interest in increasing the protein concentrations of soya bean seeds in order to improve nutritional value. Potentially this could change the amino acid composition of the protein, perhaps even negating the improved nutritional value associated with the increased protein concentration. AC Proteus is a new high protein cultivar recently developed and registered as germplasm line OT89-16. It is conventional in animal nutrition to view protein more in terms of its amino acid balance as well as total amounts. Fig 1 shows that the protein quality of Maple Arrow is superior to AC Proteus (expression of the content of an amino acid relative to lysine is a conventional means of expressing protein quality for non-ruminant livestock) although the total lysine content was much lower. AC Proteus has been bred for increased lysine content but this appears to have been achieved at the expense of other amino acids. An additional consideration to cultivation of high protein soya bean lines content is that selection for increased protein usually results in decreased yield (Helms \& Orf 1998). In barley, high $\mathrm{N}$ nutrition resulted in a greater protein concentration in the seed and a differential accumulation of seed storage protein types (Kirkman et al. 1982), although the net effect was a reduction in protein quality (Guise \& Hopp 1984).

(Figure 1 about here)

In soya bean lines from a single cross, ranging in protein concentration from $370-500 \mathrm{~g} / \mathrm{kg}$, methionine and protein concentration showed a minimal negative correlation (Burton et al. 1982). However, little has been undertaken to determine the effects of selection for high protein on amino acid composition. Serretti et al .(1994) found breeding for high protein induced significant variations in amino acid concentrations in four high protein lines (BARC-6, BARC-7, BARC-8 and BARC-9) 
compared to two normal protein controls ('Essex' and 'Manokin') but did not produce a consistent increase or decrease in all concentrations in these lines (Fig 2).

(Figure 2 about here)

Cysteine plus methionine account for 30 to $45 \mathrm{~g} / \mathrm{kg}$ of the amino acid residues of glycinin (Nielson et al. 1989). Thus the sulphur amino acid content of glycinin is similar to that of other high quality dietary proteins. Conversely, sulphur amino acids account for less than $10 \mathrm{~g} / \mathrm{kg}$ of the amino acids residues of $\exists$-conglycinin (Harada et al. 1989). The mature $\exists$-subunit of $\exists$-conglycinin is composed of approximately 416 amino acid residues and lacks both methionine and cysteine (Coates et al. 1985). Hence the $\exists$-subunit of $\exists$-conglycinin is primarily responsible for the low sulphur amino acids content of the combined soya bean storage proteins.

Imsande (1998) recently has shown that nitrogen (protein) concentration of soya bean seed is significantly affected by nitrogen source supplied to the plant during seed growth. Plants subsisting solely on $\mathrm{N}_{2}$ fixation produced low protein seed. For those grown on mineral $\mathrm{N}$, the seed contained increasingly greater protein concentration with increasing proportion of nitrogen supplied in the reduced form. Paek et al. (1997) analyzed the seed produced from these treatments to investigate how change in seed protein concentration, independent of genotype, changes seed protein composition. The results of two experiments were consistent in showing that raising soya bean seed protein concentration through enhanced plant $\mathrm{N}$ simulation results in poorer protein quality (Fig 3).

(Figure 3 about here)

It was demonstrated that the sulphur-poor $\exists$-subunit of 75 protein is more strongly expressed under conditions of nitrogen application whereas S-containing subunits are influenced less, or not at all, thereby deteriorating the $11 \mathrm{~S} / 7 \mathrm{~S}$ ratio. The failure to increase the glycinin concentration in parallel with total protein concentration could possibly be explained by a limitation of sulphur uptake and/or assimilation.

Gayler \& Sykes (1985) examined the effects of sulphur deficiency on the 
complement of proteins laid down in developing seeds of soya bean. Sulphur deficiency caused a $40 \%$ decrease in the level of glycinins and a contrasting elevation in the level of $\exists$-conglycinins. The subunit composition of these proteins was also affected. There was in particular a three fold increase in the $\exists$-subunit of $\exists$-conglycinins in the sulphur deficient seeds, and this accumulated largely as the $\mathrm{B}_{6}$ isomer of $\exists$-conglycinins, a protein which, while virtually devoid of methionine and cysteine, retains the physical properties of a normal 7S storage protein. This demonstrates that a high degree of selectivity can be exerted over the accumulation of proteins in developing seeds. Studies into the effects of nitrogen source and timing of sulphur deficiency on seed yield and expression of both $11 \mathrm{~S}$ and $7 \mathrm{~S}$ storage proteins demonstrated that sulphur assimilated during seed filling appears to be the main source of S-containing amino acids for synthesis of seed proteins. This is confirmed by the relatively weak effect of vegetative sulphur status on the 11S-7S ratio.

Free amino acids.

An alternative approach to altering the nutritionally essential amino acid profile through changing the relative contents of storage protein is to increase the levels of free amino acids in the seed. Typically the pool of any free amino acid is less than 0.05 of the protein-bound quantity. The sizes of the free amino acid pools are usually tightly regulated. The amino acid biosynthetic pathways are controlled at the enzyme level by the concentration of the amino acid products of the pathways. The enzymes at the beginning or at branch points of pathways are susceptible to inhibition or enhancement of activity by binding of amino acids to regulatory sites that affect catalytic activity. Possible approaches to increasing biosynthesis of the free amino acids includes altering the regulatory site of the native regulated enzymes or shunting around the regulated step by the introduction of an unregulated enzyme with the same catalytic specificity. Biosynthesis is then no longer inhibited by amino acid pool size. In the absence of high levels of catabolism the amino acid can accumulate to significant levels.

Early work in this area used cell culture selection approaches to identify mutants with deregulated biosynthetic pathways (Bright \& Shewry 1983). The 
standard approach is to grow cells in the presence of an amino acid analogue that inhibits growth by shutting down a biosynthetic pathway and starving the cells for the end product of the pathway. Most of the cell culture work has been done on the aspartate biosynthetic pathway which produces lysine, threonine and methionine, and on the aromatic pathway which produces tryptophan, tyrosine and phenylalanine.

Soya beans accumulate unique non-protein and free amino acids (Krober \& Gibbon 1962). However, there is little quantitative information available on the free and protein-bound amino acid contents of soya beans. It has been postulated that one or more of these unique components in the free amino acid pool is a genetically controlled characteristic of a particular species or group of species (Davis et al. 1991). The actual composition of the free amino acid pool varies, depending on maturity, nutrient supply from the soil and from fertilizer treatment, climatic conditions during growth, storage conditions and genetic factors (Krobor \& Gibbons 1962). Spencer \& Higgins (1982) have indicated that the levels of free amino acids in the pool of the developing seeds, which may be an important element in the synthesis of storage proteins, are correlated with the composition of the major storage proteins being synthesized. Accurate assessment of the free amino acid pool is essential as it affects the nutritional evaluation of non-ruminant diets based on soya bean supplemented with free amino acids.

A comparison of two Northern adapted soya bean cultivars made by Zarkadas et al. (1994), studying free amino acid profiles of the ethanol-soluble fractions showed that levels of many of the individual amino acids were similar in a high protein cultivar (AC Proteus) and a commercial strain (Maple Arrow) (See Fig 4). However, cultivar to cultivar variations in free amino acid content were significant in respect to five amino acids; aspartic acid, threonine, glycine, alanine and arginine. Further work is required to establish a database of soya bean free amino acid composition.

\section{(Figure 4 about here)}

\subsection{Altering methionine content.}

Soya bean protein quality has traditionally been lower the than the Food and 
Agricultural Organization (FAO) nutritional recommendations for methionine, cysteine and threonine (Wilson 1987). The average concentration of these amino acids in soya bean seed range from 10.7 to $12.6,12.4$ to 13.7 and 40.0 to $42.0 \mathrm{~g} / \mathrm{kg}$ crude protein for methionine, cysteine and threonine, respectively (Serretti et al. 1994). Methionine is the primary limiting amino acid in soya beans which compromises nutritional quality. Expressed as a proportion of total protein, the soya bean contains only 0.56 as much methionine and cysteine as the nutritionally complete FAO reference protein, egg protein.

Although this problem can be overcome by supplementation with free methionine and complementation with other protein-containing raw materials and cereals, these solutions are less satisfactory than improving the amino acid profile of soya beans. Leaching of methionine during processing and bacterial degradation leading to formation of undesirable volatile sulphides are associated with supplementation. The poultry and pig industry would derive considerable savings if an improved variety of soya bean overcame the requirement for supplementation of cereal-soya bean meal based animal feed with exogenous methionine.

Increasing content of high methionine protein in soya beans

One of the possible approaches to improving the nutritional quality of soya bean seed protein would be to identify endogenous methionine-rich proteins and increases their biosynthesis. George \& de Lumen (1991) combined the powerful resolution available with two dimensional gel electrophoresis and an in vitro labeling method which allowed them to identify a $10.8 \mathrm{kDa}$ protein in soya bean with an exceptionally high methionine content of $121 \mathrm{mg} / \mathrm{g}$. Determination of the $\mathrm{N}$-terminal sequence of the first 20 amino acids of this protein has revealed it to be identical to a sequence in sunflower seed 2S albumin protein that contains $150 \mathrm{mg} / \mathrm{g}$ protein. Introduction of a homologous gene encoding for an endogenous protein could lead to a more stable integration into the genome and would therefore be less likely to interfere with the normal biology of the seed compared with the introduction of a heterologous gene coding for a foreign protein. However, a 17 fold increase in the level of the methionine-rich protein identified by George \& de Lumen (1991) would be required to bring the methionine content up to that of the FAO reference protein.

The production of high methionine polypeptides has several drawbacks 
besides the fact that most alterations affect either:

a) the ability of proteins to be properly transported, processed and deposited in the storage tissue cells of developing seeds

b) this ability to be reactivated upon germination (Muntz et al. 1997).

Taken together, the results achieved so far by introducing high methionine subunits from naturally occurring globulins indicate that it will not be possible to achieve significant increases in the methionine content of the seed protein via this strategy in the near future.

Currently the most promising approach to improving methionine content is to introduce genes that have been isolated from foreign plants which code for proteins with extremely high methionine levels. The favoured subjects for such experiments are the genes encoding $2 \mathrm{~S}$ albumins from either Brazil nut (Bertholettia excelsa, H.B.K.) (Altenbach et al. 1987) or sunflower (Helianthus annuus) (Kortt \& Caldwell 1990). The feasibility of this strategy was initially shown by using the Brazil nut $2 S$ albumin gene (BNA) to transform tobacco and rape (Altenbach et al. 1989). The Brazil nut albumin gene has also been successfully used to transform soya bean (Townsend \& Thomas 1994).

Townsend \& Thomas (1994) also reported one transgenic soya bean line in which $10 \mathrm{mg} / \mathrm{g}$ of the salt-extractable seed protein was Brazil nut albumin. However, flour from this line showed only a 30\% increase in the methionine content as compared to the wild-type. Here it appears that the formation of some endogenous methionine-containing proteins are suppressed by the metabolic demands imposed by expressing the high levels of Brazil nut albumin. The Brazil nut albumin acts as a strong methionine sink which, in soya bean, out-competes the formation of at least some of the other methionine-containing endogenous proteins. In addition, Muntz et al. (1997) reported that the increased methionine levels occurred at the cost of other non-protein sulphur compounds. It is not yet known whether the total amount of sulphur-containing compounds that can be formed in transgenic seeds is limited by available sulphur. Future experiments using cotyledon culture or whole plants are necessary to determine whether an additional sulphur supply could prevent the reallocation of sulphur among the endogenous sulphur-containing compartment of 
the seed.

Horta \& Sodek (1997) report that the in vitro culture of isolated, immature soya bean cotyledons (in direct contact with the medium) on a defined medium containing glutamine and methionine as sole sources of nitrogen and sulphur for 7 days led to rates of growth and reserve protein accumulation close to, or greater than, those occurring in situ. It was also noted that methionine suppressed synthesis of the $7 \mathrm{~S}$ subunit and the free amino acid pool was increased more than fifty-fold (see Table 4). However, many other amino acids also showed large increases. It was concluded that the data showed that an abnormal situation arises on culturing with a methionine-containing medium, a fact with must be considered before attributing the affects on growth and protein synthesis directly to methionine.

(Table 4 about here)

Following the discovery that Brazil nut albumin was the major allergen of Brazil nut, there have been new arguments against employing genetic engineering for improvement of nutritional value.

\section{Mutants}

Mutations are part of the basic phenomena of life. Natural mutations have allowed living material to adapt and develop to different ecological conditions. Changes in the genetic code are translated into changes in the proteins synthesized. Hence beneficial changes to the amino acid profile of soya bean storage proteins caused by mutation may be used to develop new cultivars.

\section{Glycinin}

Screening of USA and Japanese germplasm collections has resulted in the recovery of a number of mutants that either lack individual 75 or $11 S$ subunits or which contained aberrant subunits. One of the earliest mutants that was discovered was found in the Japanese variety 'Raiden'. It was first noticed because there was a discrepancy between the number of glycinin units described by research groups (Kitamura \& Shabasaki 1975; Moreira et al. 1981). Staswick \& Nielson (1983) 
demonstrated that the $G 4$ subunit $\left(A_{4} A_{5} B_{3}\right)$ in the CX635-1-1-1) cultivar was absent in Raiden. A partial screening of the USDA-ARS (USA) germplasm collection revealed that this mutation is fairly commonly encountered (Nielson, unpublished data, reported by Nielson and Nam, (in press). Later it was shown that the allele that caused this subunit to be absent from the seed was inherited as a genetic recessive (Scallon et al. 1987). Recently, a mutant that apparently lacks the Gy5 gene product in a collection of Glycine soja was described by Kitamura (1993). Subunits from Gy5 play an important role in determining gel hardness and transparency in tofu (Nakamura et al. 1986). Because G. soja has cross-compatibility with the domesticated soya bean Glycine max), it should be possible to introduce this trait into cultivated varieties. Many other glycinin mutations are also described in the literature (reviewed by Nielson and Nam, in press).

\section{Conglycinin}

A number of mutations have been discovered that effect the $\exists$-conglycinin subunit genes. The Japanese variety 'Kiburi' is characterized by the absence of the $\forall$ ' subunit, a recessive genetic allele (Kitamura et al. 1984) that appears to be the result of a small deletion. One report describes independent, single recessive genes that strongly reduce the amount of $\forall$ - and $\exists$-subunits accumulated in seeds (Tsukada et al. 1986). Because the $\exists$-subunits accumulated in the seed are the products of multiple genes (Harada et al. 1989), it is difficult to rationalize this result unless the mutation is in a gene that in some manner regulates the accumulation of these subunits. Hayashi et al. (1998) recently characterized a soya bean mutant lacking the 7S subunits, $\forall, \forall \mathrm{N}$ and $\exists$ in an attempt to elucidate the complexities of regulation of $7 \mathrm{~S}$ subunit expression. The results indicated that the deficiency is not caused by a lack of, or structural defects in, the $7 \mathrm{~S}$ globulin subunit genes, but rather arises at the mRNA level.

It has become possible to breed soya bean varieties with a markedly modified protein composition ranging from extremely high to extremely low 75 to $11 \mathrm{~s}$ ratios using mutant genes for the two soya bean storage globulins. Kitamura (1995) described a modification of the storage seed protein composition using mutant genes that produced a low $7 \mathrm{~S}$ line where the $7 \mathrm{~S}$ globulin content was only about half that of 
ordinary varieties, whereas the $11 \mathrm{~S}$ globulin content was approximately $15 \%$ higher than that of ordinary varieties. Consequently, the total protein content remained about the same in both mutant and ordinary varieties. By manipulating the variant alleles identified so far, it is possible to develop varieties with extremely high $11 \mathrm{~S}: 7 \mathrm{~S}$ ratios which may improve nutritional value. Genotypic variation for $11 \mathrm{~S}: 7 \mathrm{~S}$ is low among cultivated soya bean (Glycine max. (L) Merrill) germplasm but ratios ranging from 1.7-4.9 have been observed among accessions of the wild ancestor of cultivated soya bean Glycine soja. Thus the wild soya bean germplasm was evaluated as a source of genes that govern protein synthesis that may have been lost during the domestication of Glycine max. It was concluded that Glycine soja may have a different complement of genes that influence the expression of $11 \mathrm{~S}$ and $7 \mathrm{~S}$ proteins than Glycine max. germplasm and suggested wild soya beans may be a useful genetic resource for the further improvement of protein quality in cultivated soya beans (Kwanyen et al. 1997).

\section{HIGH PROTEIN SOYA BEAN IN DIETS FOR NON-RUMINANTS}

It is crucial that any developments in plant breeding designed to improve the nutrient content of soya beans are accompanied by studies which establish whether a total increase in a nutrient is associated with, at the least, a similar nutritional value (e.g. nutrient utilization which may be assessed through digestibility or performance studies where growth and efficiency of food conversion are evaluated). However there would appear to have been only limited studies in this general area which suggests that there is considerable scope for further investigations particularly with the emergence of an increasing number of novel cultivars.

As described earlier, AC Proteus, a new cultivar of soya bean recently developed and registered as germplasm line OT89-16, is primarily intended as an animal feed because it contains more protein $(440-480 \mathrm{~g} / \mathrm{kg}$ ) and less oil $(150-180 \mathrm{~g} / \mathrm{kg})$ than conventional soya beans that were developed for oil production (Voldeng et al. 1996). Zarkadas et al. (1993) reported that the content of essential amino acids in AC Proteus was excellent (although, as outlined earlier, the balance of amino acids is not as with conventional cultivars). Growth performance of birds fed diets containing full fat high protein soya beans was similar to that obtained with diets containing conventional soya beans when the diets were isonitrogenous and 
isoenergetic (see Table 5).

(Table 5 about here)

For pig diets, the combination of higher protein and lower oil concentrations in AC Proteus compared to conventional soya bean has the potential benefit of a more optimal protein-to-energy ratio in the diet as well as a reduction in the quantity of soya bean required to reach the recommended levels of amino acids in the diet.

McNiven \& Castell (1996) demonstrated AC Proteus could replace soya bean meal or full fat soya bean on an equivalent protein basis, potentially reducing the cost of protein supplementation in pig starter diets (Table 6).

(Table 6 about here)

\section{CONCLUSIONS}

No one raw material contains all the nutrients and energy-yielding components in the correct proportions necessary to support optimum growth and performance of non-ruminant farm animals which is the reason why compound diets are formulated with the objective of correcting individual imbalances. However, there is considerable scope for increasing concentrations of those nutrients known to be deficient. In the case of soya beans, which are the most important protein-containing crop worldwide, relative deficiencies of nutritionally essential amino acids have been recognized as limitation to their increased use. Knowledge of the biosynthetic pathways responsible for the synthesis of the major proteins contained within the seed and the inherent genetic variability amongst cultivars has potential for generating improved lines. A major future research effort will be to confirm that any such developments are associated with improved nutritional value. 


\section{REFERENCES}

Altenbach, S.B, Pearson, K.W., Leung, F.W. and Sun, S.S. (1987). Cloning and sequence analysis of a cDNA encoding a Brazil nut protein exceptionally rich in methionine. Plant Molecular Biology 8, 239-250.

Altenbach, S.B, Pearson, Meeker, G., Staracl, L.C. \& Sun, S.S. (1989). Enhancement of the methionine content of seed proteins by the expression of a chimaeric gene encoding a methionine-rich protein in transgenic plants. Plant Molecular Biology 13, 513-522.

BRIGHT, S.W.J. \& SHEWRY, P.R. (1983). Improvement of protein quality in cereals. CRC Critical Reviews in Plant Sciences. 1, 49-93.

BRIM, C.A. \& BURTON, J.W. (1979). Recurrent selection in soyabeans. II, Selection for increased percent protein in seeds. Crop Science 19, 494-498.

BURTON, J.W., PURCELL, A.E. AND WALTER, W.M. (1982). Methionine concentration in soyabean protein from populations selected for increased percent protein. Crop Science 22, 430-432.

CATSIMPOOLAS, N. (1969). Isolation of glycinin subunit by isoelectric focusing in urea mercaptoethanol. FEBS Letters 4, 259-261.

CATSimpoolas, N. \& EkENSTAM C. (1969). Isolation of a-, b- and t-conglycinins. Archives of Biochistry and Biophysics 129, 490.

Coates, J.B., MedeiRos, J.S., Thanh, V.H. \& Nielsen, N.C (1985). Characterisation of the subunits of b-conglycinin. Archives of Biochemistry and Biophysics 243, 184-189.

Chohan, A.K., Hamilton, R.M.G., McNiven, M.A. \& MacLoed, J. (1993). High protein and low trypsin inhibitor varieties of full fat soyabeans in broiler chicken starter diets. Canadian Journal of Animal Science 73, 401-409.

Danielsson, C.E. (1949). Seed globulins of the gramineae and leguminosae. Biochemistry Journal 44, 387-400.

Davis, A.J., Hurthouse, M.B., Motevalli, M., O'Brien, P. \& Nunn, P.B. (1991). The crystal structures of two plant non-protein neurotoxic amino acids. Phytochemistry $\mathbf{3 0}$, 3635-3638.

GAYLER, K.R. \& SYKES, G.E. (1985). Effects of nutritional stress on the storage proteins of soyabeans. Plant Physiology 78, 582-585.

GEORGE, A.A. \& DE LUMEN, B.O. (1991). A novel methionine-rich protein in soyabean seed: identification, amino acid composition and $\mathrm{N}$-terminal sequence. Journal of Agricultural and Food Chemistry 39, 224-227.

GUISE, H. \& HOPP, H.E. (1984). Influence of nitrogen nutrition on the amount of 
hordein, protein $Z$ and $b$-amylase messenger RNA in developing endosperms of barley. Carlsberg Research Communication 49, 365-383.

HARAdA, K., ToyokaWA, Y. \& KitAmuRA, K. (1983). Genetic analysis of the most acidic $11 S$ globulin subunit and related characters in soyabean seeds. Japanese Journal of Breeding 33, 23-30.

HARADA, J.J., BARKER, S.J. \& GoldBERG, R.B. (1989). Soyabean b-conglycinin genes are clustered in several DNA regions and are regulated by transcriptional and post-transcriptional processes. Plant Cell 1, 415-425.

HARTWIG, E.E. \& HINSON, K. (1972). Association between chemical composition of seed and seed yield of soyabeans. Crop Science 12, 829-830.

Hayashi, M., Harada, K., Fujiwara, T. \& KitamuRA, K. (1998). Characterisation of a $7 S$ globulin-deficient mutant of soybean (Glycine max (L.) Merrill). Molecular and General Genetics. 258, 208-214.

HeLms, T.C. AND ORF, J.H. (1998). Protein, oil and yield of soyabean lines selected for increasedprotein. Crop Science. 39, 707-711.

HILL, J.E. \& BREIDENBACH, R.W. (1974). Proteins of soyabean seeds. I: Isolation and characterisation of the major components. Plant Physiology 53, 742-746.

HORTA, A.C.G. \& SODEK, L. (1997). Free amino acid and storage protein composition of soyabean fruit explants and isolated cotyledons cultured with and without methionine. Annals of Botany. 79, 547-552.

IMSANDE, J. (1998). Nitrogen deficiency during soybean pod fill and increase plant biomass by rapid $\mathrm{N}_{2}$ fixation. European Journal of Agronomy 8, 1-11.

JuviK, G.A., Bernard, R.L., Chang, R. \& CAVInS, J.F. (1989a). Evaluation of the USDA wild soybean germplasm collection: Maturity groups 000-IV (PI 65.549 to PI 483.464). United States Department of Agriculture, Agricultural Research Service Technical Bulletin No. 1761. National Technical Information Service, Springfield, V.A.

Juvik, G.A., Bernard, R.L., Chang, R. \& Cavins, J.F. (1989b). Evaluation of the USDA wild soybean germplasm collection: Maturity groups 000-IV (PI 446.893 to PI 486.355). United States Department of Agriculture, Agricultural Research Service Technical Bulletin No. 1760. National Technical Information Service, Springfield, V.A.

KIRKMAN, M.A., SHEWRY, P.A. \& MIFLIN, B.J. (1982). The effect of nitrogen nutrition on the lysine content and protein composition of barley seeds. Journal of the Science of Food and Agriculture 33, 115-127

KITAMURA, K. (1993). Breeding trials for improving the food processing quality of soyabeans. Trends in Food Science and Technology 4, 64-67.

KITAMURA, K. (1995) Genetic improvement of nutrition and food processing quality in soyabean. Japansese Agriculture Research Quarterly 29, 1-8. 
KITAMURA, K. \& SHIBASAKI, K. (1975). Isolation and some physicochemical properties of the acidic subunits of soyabean $11 \mathrm{~S}$ globulin. Agriculture and Biological Chemistry 39, 945-951.

KitamuRa, K., Toyokawa, Y. \& HaRada, K. (1980). Polymorphism of glycinin in soyabean seeds. Phytochemistry 19, 1841-1843.

KitamuRa, K., DaVies, C.S. \& Nielson, N.C. (1984). Inheritance of alleles for Gy1 and Gy4 storage protein genes in soyabean. Theoretical and Applied Genetics 68, 253-257

KORTT, A.A. \& CALDWELL, J.B. (1990). Low molecular weight albumins from sunflower seeds: identification of a methionine-rich albumin. Phytochemistry 29, 2805-2810.

KROBER, O.A. \& GibBONS, S.J. (1962). Non-protein nitrogen in soyabeans. Journal of Agricultural and Food Chemistry 10, 57-59.

Kwanyuen, P., Pantalone, V.R., Burton, J.W. \& Wilson, R.F. (1997). A new approach to genetic alteration of soybean protein composition and quality. Journal of the American Oil Chemists Society 74(8), 983-987.

KWANYUen, P., WiLson, R.F. \& BURTon, J.W. (1998). Soybean Protein Quality. In Proceedings of the World Conference on Oilseed and Edible Oil Processing Volume I AOCS Press, Illinois. pp. 284-289.

LEI, M.-G. \& REECK, G.R.(1987). Two dimensional electrophorectic analysis of the proteins of isolated soybean protein bodies and of the glycosylation of soybean proteins. Journal of Agricultural and Food Chemistry 35, 296-300.

MCNiven, M.A. \& CASTELL, A.G. (1996). High protein soyabean as a source of protein and energy for starter pigs. Canadian Journal of Animal Science 76, 417-422.

MEDEIROS, J.S. 1982). Characterisation of the subunits of beta-conglycinin, and the application of the enzyme-linked immunosorbent assay (ELISA) to the determination of the contents of the beta-conglycinin and glycinin in soyabean (Glycine max) seeds. Ph.D. dissertation, Purdue University, West Lafayette, IN 47907.

MEINKE, D.W., Chen, J. \& Beachy, R.N. (1981). Expression of storage protein genes during soyabean seed development. Planta 153, 130-139.

Moreira, M.A., Hermodson, M.A., Larkins, B.A. \& Nielson, N.C. (1979). Partial characterisation of the acidic and basic polypeptides of glycinin. Journal of Biological Chemistry 254, 9921-9926.

Moreira, M.A., Hermodson, M.A., Larkins, B.A. \& Nielson, N.C. (1981). Comparison of the primary structure of the acidic polypeptides of glycinin. Archives of Biochemistry and Biophysics 210, 633-642.

Morita, S., Fukase, M. Hoshino, K., KukadA, Y., YAmaguchi, M. \& MoRitA, Y. (1994). 
A serine protease in soyabean seeds that acts specifically on the native a subunit of b-conglycinin. Plant Cell Physiology 35(7), 1049-1056.

Morita, S., Fukase, M., Yamaguchi, M., Fukuda, Y. \& Morita, Y. (1996). Purification, characterisation and crystallisation of single molecular species of b-conglycinin from soyabean seeds. Bioscience and Biotechnical Biochemistry 60(5), 866-873.

Muntz, K., Christov, V., Jung, R., SaAlbach, G., Waddell, D., Pickardt, T. \& SCHIEDER, O. (1997). Genetic engineering of high methionine proteins in grain legumes. In Sulphur metabolism in Higher Plants. pp. 71-86. Eds W.J. Cram, L.J. LeKok, I. Stulen, C. Brunold and H. Rennenberg. Leiden, The Netherlands: Backheys Publishers.

MuRPhy, P.A. \& RESURRECCION, A.P. (1984). Varietal and environmental differences in soyabean glycinin and ß-conglycinin concentration. Journal of Agricultural and Food Chemistry 32, 911-915.

NAISMITH, W.E.F. (1955). Ultracentrifuge studies on soyabean protein. Archives of Biochemistry and Biophysics. 16, 203-210.

NiELson, N.C. (1985). Structure of soya proteins. In New Protein Foods, Vol. 5 Seed Storage Proteins. Eds A.M Altschul \& H.L. Wilke. pp.27-64. Orlando, Florida: Academic Press.

Nielson, N.N. \& NAM, Y-W. (1999). Soybean globulins. In: Seed Proteins.P.R Shewry \& R Casey (Ed). Kluwer Academic Publishers, Dordrecht. pp 285-313

Nielson, N.C., Dickinsen, T.-J., Cho, V.H., Thanh, V.H., Scallon, B.J., Fischer, R.L., Sims, T.L., DreWS, G.N. \& Goldberg, R.G. (1989). Characterisation of the glycinin family in soyabean. Plant Cell. 1, 313-328.

NAKAMURA, T., UTSUMI, S. \& MORI, T. (1986). Mechanism of heat-induced gelation and gel properties of soyabean 7S globulin. Agricultural and Biological Chemistry 50, 1287-1293.

Ogawa, T., Tayama, E., Kitamura, K. \& Kaizuma, N. (1989). Genetic improvement of seed storage protein using three variant alleles of $7 \mathrm{~S}$ globulin subunits in soyabean. (Glycine max L.) Japanese Journal of Breeding 39, 137-147.

OsboRne, T.B. (1924). The vegetable protein. Monographs in Biochemistry London: Longmans, Green \& Co.

Osborne, T.B. \& CAmpbelL, G.F. (1898). Proteins of the pea. Journal of the American Chemical Society 20, 348-362.

PAEk, N.C., ImSANDE, J., Shoemaker, R.C. \& Shibles, R. (1997). Nutritional control of soyabean seed storage protein. Crop Science 37, 498-503.

Pernollet, J.-C. \& Mosse, J. (1983). Structure and location of legume and cereal 
seed storage proteins. No.20 in Seed Proteins. J. Daussant, J. Mosse \& J. Vaughan (Ed.), Annual Proceedings of the Phytochemical Society of Europe Academic Press, London. pp.159-190.

Probst, A.H., Laviolette, F.A., Athow, K.L. \& Wilcox, J.R. (1971). Registration of Protana soyabean. Crop Science 11, 312.

SATO, K. \& IKEDA, T. (1979). The growth responses of soyabean to photoperiod and temperature. IV. The effect of temperature during the ripening period on the yield and characters of seed. Japanese Journal of Crop Science 48, 283-290.

SCAllon, B.J., Dickenson, C.D. \& Nielson, N.C. (1987). Characterisation of a null-allele for the Gy4 glycinin gene from soyabean. Molecular and General Genetics 208, 107-113.

Schou, J.B., Jeffers, D.L. \& Streeter, J.G. (1978). Effects of reflectors, black boards or shades applied at different stages of plant development on yield of soyabeans. Crop Science 18, 29-34.

Serretti, C., Schapaugh, W.T., JR. \& LefFel, R.C. (1994). Amino acid profile of high protein soyabean. Crop Science 34, 207-209.

SPENCER, D. \& Higgins, T.J.V. (1982). Seed maturation and deposition of storage proteins. In The molecular biology of plant development. Eds H. Smith \& D. Grierson. Vol. 18, pp.306-336. Oxford, UK: Blackwell Scientific Publications.

Staswick, P.E. \& Nielson, N.E. (1983). Characterisation of a soyabean cultivar lacking certain glycinin subunits. Archives of Biochemistry and Biophysics 223, 1-8.

Staswick, P.E., Hermodson, M.A. \& Nielsen, N.C. (1981). Identification of the acidic and basic subunit complexes of glycinin. Journal of Biological Chemistry 256, 8752-8755. 
StREeTER, J.G. \& JeFFERS, D.L. (1979). Distribution of total nonstructural carbohydrates in soyabean plants having increased reproductive loads. Crop Science 19, 729-734.

SYKES G.E. \& GAYLER, E.R. (1981). Detection and characterisation of a new b-conglycinin from soyabean seeds. Archives of Biochemistry and Biophysics 210, 525.

THANH, V.H. \& SHIBASAKI, K. (1976a). Major proteins of soyabean seeds. A straight forward fraction and their characterisation. Journal of Agricultural and Food Chemistry 24(6), 1117-1121.

THANH, V.H. \& SHIBASAKI, K. (1976b). Heterogeneity of ß-conglycinin. Archives of Biochemistry and Biophysics 439, 326-338.

THANH, V.H. \& SHIBASAKI, K. (1979). Major proteins of soyabean seeds. Reconstitution of b-conglycinin from its subunits. Journal of Agricultural and Food Chemistry 26, 695.

TOWNSEND, J.A. \& THOMAS, L.A. (1994). Factors which influence the Agrobacterium-mediated transformation of soyabean. Journal of Cell Biochemistry Suppl. 18A, Abstr.X1-014.

Tsukada, Y., Kitamura, K., HaRada, K. \& Kaizuma, N. (1986). Genetic analysis of subunits of two major storage proteins (b-conglycinin and glycinin) in soyabean seeds. Japanese Journal of Breeding 36, 390-400.

Voldeng, H.D., Guillemette, R.J.D., Leonard, D.A. \& Cober, E.R. (1996). AC Proteus Soyabean. Canadian Journal of Plant Science 76, 153-154.

Weber, C.R. \& FeHR, W.R. (1970). Registration of Provar soyabeans. Crop Science 10, 728 .

Wehrman, V.K., Fehr, W.R., Cianzio, S.R. \& CaVins, J.F. (1987). Transfer of high seed protein to high-yielding soyabean cultivars. Crop Science 27, 927-931.

WILCOX, J.R. \& CAVINS, J.F. (1995). Backcrossing high seed protein to a soyabean cultivar. Crop Science 35, 1036-1041.

WILSON, R.F. (1987). Seed Metabolism. In: Soyabeans, Improvement, Production and Uses, 2nd Ed. Wilcox, J.R. (Ed.). Publisher Madison, Wisconsin, USA. pp.643-686.

WolF, W.J. \& CoWAN, J.C. (Ed.) (1975). Soyabeans as a Food Source. CRC Press, Cleveland, $\mathrm{OH}$.

Yamauchi, Sato, M., Sato, W., Kamata, Y. \& Shibasaki, K. (1981). Molecular understanding of heat-induced phenomena in soyabean protein. Food Review International 7, 283-322. 
1 Zarkadas, C.G., Yu, Z., Voldeng, H.D. \& Minero-Amador, A. (1993). Assessment of 2 the protein quality of a new high-protein soyabean cultivar by amino acid analysis. 3 Journal of Agricultural and Food Chemistry 41, 616-623.

4

5 Zarkadas, C.G., Yu, Z., Voldeng, H.D., Hope, H.J, Minero-Amador, A. \& 6 Rochemont, J.A. (1994). Comparison of the protein-bound and free amino acid 7 contents of two Northern adapted soyabean cultivars. Journal of Agricultural and 8 Food Chemistry 42, 21-33. 
1 Table 1. Globulin-type protein composition of soya bean seed.

2

3

4

\begin{tabular}{|c|c|c|c|c|c|}
\hline \multirow[t]{2}{*}{ Sv Units } & \multirow[t]{2}{*}{ Nomenclature } & \multirow{2}{*}{$\begin{array}{c}\text { Content } \\
\text { (mg/g } \\
\text { globulin) }\end{array}$} & \multirow{2}{*}{$\begin{array}{c}\text { Molecular } \\
\text { Weight } \\
\text { kDa }\end{array}$} & \multicolumn{2}{|c|}{ Amino Acid } \\
\hline & & & & $\begin{array}{c}\text { Methionine } \\
(\mathrm{mg} / \mathrm{g})\end{array}$ & $\begin{array}{c}\text { Cysteine } \\
(\mathrm{mg} / \mathrm{g})\end{array}$ \\
\hline $2 \mathrm{~S}$ & $\forall$-Conglycinin. & 127 & $18-33$ & 50 & 48 \\
\hline $7 S$ & $\exists$ - Conglycinin & 30 & 104 & 14 & 22 \\
\hline $7 S$ & $\vartheta$-Conglycinin & 350 & $141-171$ & 14 & 22 \\
\hline $11 \mathrm{~S}$ & Glycinin & 418 & $317-360$ & 15 & 30 \\
\hline $15 \mathrm{~S}$ & Poly-glycinin & 75 & ND & ND & ND \\
\hline
\end{tabular}

5

6 Sv: Svedberg Units

7 ND: not determined. (Wilson 1987). 
2 Table 2. Major soya bean glycinin subunits (Nielson 1985).

3

\begin{tabular}{|ccccc|}
\hline & & Molecular & Number of \\
Group & Subunit & Subunit & Weight. & $\begin{array}{c}\text { Methionine } \\
\text { Residues }\end{array}$ \\
I & G1 & $\mathrm{A}_{1 \mathrm{a}} \mathrm{B}_{2}$ & 58 & $5-6$ \\
I & G2 & $\mathrm{A}_{1 \mathrm{~b}} \mathrm{~B}_{1 \mathrm{~b}}$ & 58 & $5-6$ \\
II & $\mathrm{G} 3$ & $\mathrm{~A}_{2} \mathrm{~B}_{1 \mathrm{a}}$ & 58 & $7-8$ \\
II & $\mathrm{G} 4$ & $\mathrm{~A}_{3} \mathrm{~B}_{4}$ & 62 & 3 \\
\hline
\end{tabular}

4 
3 Table 3. Effect of increased light induced by mirror reflectors at the soil level 4 on seed development (Schou et al. 1978).

5

\begin{tabular}{|l|c|c|c|c|}
\hline & \multicolumn{2}{|c|}{1973} & \multicolumn{2}{c|}{1974} \\
\hline Variable & Reflectors & Controls & Reflectors & Controls \\
\hline $\begin{array}{l}\text { Weight of } 100 \text { seeds } \\
(\mathrm{g})\end{array}$ & 20.7 & 20.3 & 19.8 & 20.2 \\
\hline Seed (no./pod) & 2.0 & 2.2 & 2.1 & 1.9 \\
\hline Fruit weight (g/plant) & 24.3 & 17.1 & 31.4 & 25.8 \\
\hline Pods/plant (no.) & & & 48.25 & 45.75 \\
\hline
\end{tabular}

6

7

8

9 
1 Table 4. Dry weight, storage protein and free amino acid accumulation in 2 isolated soya beans cultured on different sulphur sources for 7 days (Horta \& 3 Sodek 1997).

4

\begin{tabular}{|l|c|c|c|}
\hline Treatment & $\begin{array}{c}\text { Dry Weight } \\
\text { (mg/cotyledon } \\
\text { pair) }\end{array}$ & $\begin{array}{c}\text { Protein } \\
\text { (mg/cotyledon } \\
\text { pair) }\end{array}$ & $\begin{array}{c}\text { Free amino acids } \\
(\mu \mathrm{mol} / \text { cotyledon) }\end{array}$ \\
\hline Initial & 13.9 & 2.7 & 0.8 \\
\hline BM & 42.4 & 10.3 & 32.5 \\
\hline BM + Met & 48.0 & 11.7 & 54.9 \\
\hline BM - S & 30.6 & 4.4 & 34.4 \\
\hline BM - S + Met & 49.3 & 11.6 & 55.0 \\
\hline In situ & 28.6 & 4.7 & 1.3 \\
\hline
\end{tabular}

5

6 BM: Basal medium with glutamine as source of $\mathrm{N}$; - S: inorganic sulphur removed; + 7 Met: methionine $(8.4 \mathrm{mM})$ added. 
2 Table 5. Effect of high \& conventional protein soya bean (autoclaved) on 3 growth, feed efficiency and nutrient digestibility in broiler chickens (Chohan et 4 al. 1993).

5

\begin{tabular}{|l|c|c|}
\hline & $\begin{array}{c}\text { Conventional soya } \\
\text { bean }\end{array}$ & $\begin{array}{c}\text { High protein soya } \\
\text { bean }\end{array}$ \\
\hline 21 day weight $(\mathrm{g})$ & 550.7 & 567.1 \\
\hline 7-21 day gain $(\mathrm{g})$ & 422.1 & 439.5 \\
\hline 7-21 day feed intake $(\mathrm{g})$ & 660.3 & 643.2 \\
\hline Feed / gain & 1.56 & 1.47 \\
\hline Coefficient of digestibility of: & & \\
\hline Dry matter & 0.933 & 0.944 \\
\hline Crude protein & 0.903 & 0.916 \\
\hline Gross Energy (metabolizability) & 0.942 & 0.952 \\
\hline
\end{tabular}


3 Table 6. Performance effects of replacing a normal cultivar (Baron) with a high 4 protein soya bean (AC Proteus) on an isonitrogenous, isoenergetic basis 5 (McNiven \& Castell 1996).

6

\begin{tabular}{|l|c|c|c|c|}
\hline & $\begin{array}{c}\text { Soya bean } \\
\text { (g/kg diet) }\end{array}$ & $\begin{array}{c}\text { Average } \\
\text { daily gain } \\
\text { (g/day) }\end{array}$ & $\begin{array}{c}\text { Average daily } \\
\text { feed intake } \\
\text { (g/day) }\end{array}$ & $\begin{array}{c}\text { Gain:feed } \\
\text { ratio }\end{array}$ \\
\hline Baron & 177 & 600 & 915 & 0.652 \\
\hline AC Proteus & 140 & 577 & 882 & 0.651 \\
\hline
\end{tabular}

7 
1 Figure 1. Amino acid profile relative to lysine of a commercial cultivar (Maple 2 Arrow) and a high protein cultivar (AC Proteus) of soya bean (Zarkadas et al. 3 1994).

4

5 A. Essential amino acids (for non-ruminants) 
1 Figure 1. Amino acid profile relative to lysine of a commercial cultivar (Maple 2 Arrow) and a high protein cultivar (AC Proteus) of soya bean (Zarkadas et al. 3 1994).

4

5 B. Non-Essential amino acids (for non-ruminants) 
1 Figure 2. Amino acid profiles relative to lysine of high-protein soya bean lines 2 averaged across eight environments.

3 (Serretti et al. 1994)

4

$5 \quad$ A. Essential amino acids (for non-ruminants) 
1 Figure 2. Amino acid profiles relative to lysine of high-protein soya bean lines 2 averaged across eight environments.

3 (Serretti et al. 1994)

4

5

B. Non-Essential amino acids (for non-ruminants) 
1 Figure 3. Effect of nitrogen source on 11S/7S ratio.

2

3

4

5

6

7

8

Key: $0: \quad 4 \mathrm{mM} \mathrm{KNO}_{3}$,

2. $2 \mathrm{mM} \mathrm{NH}_{4} \mathrm{NO}_{3}$ (and $1 \mathrm{mM} \mathrm{KNO}_{3}$ urea $+2 \mathrm{mM} \mathrm{KNO}_{3}$ )

$3 \quad 1.5 \mathrm{mM}$ urea $+1 \mathrm{mM} \mathrm{KNO} 3$

$42 \mathrm{mM}$ urea.

$\mathrm{Y}=+1 . .6774-0.1089 \mathrm{x}$ 
1 Figure 4 Amino acid contents of the ethanol-soluble fraction isolated from two 2 Northern hemisphere soya bean cultivars after ethanol extraction (Zarkadas et 3 al. 1994).

4

5 A. Essential amino acid (for non-ruminants) 
1 Figure 4 Amino acid contents of the ethanol-soluble fraction isolated from two 2 Northern hemisphere soya bean cultivars after ethanol extraction (Zarkadas et 3 al. 1994).

4

5 B. Non-Essential amino acid (for non-ruminants) 
1 Developments in Plant Breeding For Improved Nutritional Quality of Soya Beans

2

3

4 E J Clarke and J. Wiseman

5

6 Figure 4B 